\title{
Assessment of Undiscovered Oil and Gas Resources of the Raton Basin-Sierra Grande Uplift Province of New Mexico and Colorado, 2004
}

Ing geology-based
assessment methods,
the U.S. Geological Survey
estimated a mean of
2.35 trillion cubic feet of
undiscovered natural gas
and a mean of 28.1 million
barrels of undiscovered
natural gas liquids in the
Raton Basin-Sierra Grande
Uplift Province. This is a
gas-prone province with
very limited oil production or
resources; for this reason,
oil resources were not
assessed.

\section{Introduction}

The U.S. Geological Survey (USGS) recently completed an assessment of the undiscovered oil and gas potential of the Raton Basin-Sierra Grande Uplift Province of northeastern New Mexico and southeastern Colorado (fig. 1). The assessment included the Raton Basin, the Las Vegas subbasin, and the Sierra Grande uplift. The assessment is based on the geologic elements of each Total Petroleum System (TPS) defined within the province, including hydrocarbon source rocks (source-rock maturation, hydrocarbon generation and migration), reservoir rocks (depositional setting and petrophysical properties), and hydrocarbon traps (trap formation

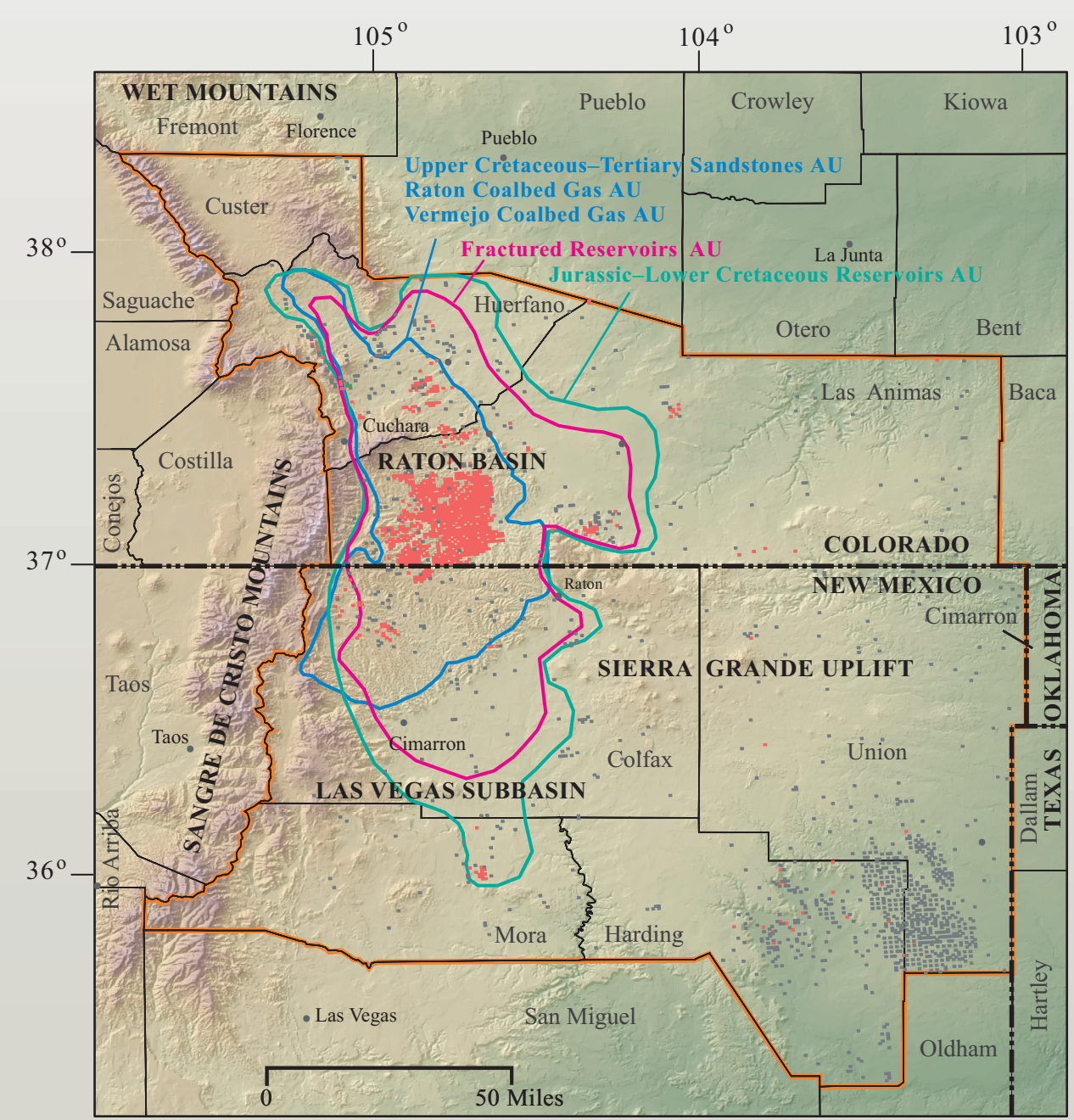

Figure 1. Raton Basin-Sierra Grande Uplift Province (orange line) of northeastern New Mexico and southeastern Colorado. The Upper Cretaceous-Tertiary Coalbed Gas Total Petroleum System (TPS) contains the Upper Cretaceous-Tertiary Sandstones, Raton Coalbed Gas, and Vermejo Coalbed Gas AUs (blue line). The Jurassic-Cretaceous Composite TPS contains the Fractured Reservoirs AU (pink line) and the Jurassic-Lower Cretaceous Reservoirs AU (green line). Red and gray squares within the AU boundaries are, respectively, cells that produce hydrocarbon gas and those that do not produce hydrocarbons. Two green cells near the northwest boundary of the AUs are oil productive. Cell sizes are about 1 mile square. Gas-productive cells contain at least one well that is gas productive and may also include nonproductive wells. Red and gray cells outside AU boundaries are not productive of hydrocarbons; they are instead dry or productive of carbon dioxide, nitrogen, and helium. 
and timing). Using this geologic framework, the USGS defined (1) the Upper Cretaceous-Tertiary Coalbed Gas TPS containing one conventional oil and gas assessment unit (AU) (Upper Cretaceous-Tertiary Sandstones AU) and two continuous oil and gas assessment units (Raton Coalbed Gas AU and Vermejo Coalbed Gas AU), and (2) the Jurassic-Cretaceous Composite TPS containing two conventional oil and gas assessment units (Fractured Reservoirs AU and Jurassic-Cretaceous Reservoirs AU). Undiscovered oil, gas, and natural gas liquids resources were quantitatively estimated within the five AUs (table 1).

\section{Resource Summary}

The USGS assessment of undiscovered conventional oil and gas and undiscovered continuous (unconventional) oil and gas within the province resulted in mean estimates of 2.35 trillion cubic feet of gas (TCFG) and 28.1 million barrels of total natural gas liquids (table 1). Undiscovered continuous resources are estimated at 1.59 TCFG from Raton and Vermejo Formation coals of the Upper Cretaceous-Tertiary Coalbed Gas TPS. The remainder of the undiscovered resources is probably structurally and (or) stratigraphically trapped conventional gas accumulations and possible unconventional gas within sandstones and shales ranging in age from Jurassic to Tertiary.

\section{For Further Information}

Supporting geologic studies of TPS and AU results, and reports on the methodology used in the Raton BasinSierra Grande Uplift Province assessment, are in progress. Assessment results are available at the USGS Central Energy Team Web site, accessed March 1, 2005. http://energy.cr.usgs.gov/oilgas/noga/

\section{Raton Basin-Sierra Grande Uplift Province Assessment Team:}

Debra K. Higley (higley@usgs.gov), Troy A. Cook, Richard M. Pollastro, Ronald R. Charpentier, Timothy R. Klett, and Christopher J. Schenk.

Table 1. Raton Basin-Sierra Grande Uplift Province assessment results listed by name and code of Total Petroleum System (TPS) and Assessment Unit (AU).

[Resources are undiscovered oil, gas, and (or) natural gas liquids. MMBO, million barrels of oil; BCFG, billion cubic feet of gas; MMBNGL, million barrels of natural gas liquids. Type refers to mainly oil or gas accumulations in the assessment unit. CBG is coalbed gas. Fractiles are fully risked estimates. F95 represents a 95-percent chance of at least the amount tabulated. Other fractiles are defined similarly. Fractiles are additive under the assumption of perfect positive correlation]

\begin{tabular}{|c|c|c|c|c|c|c|c|c|c|c|c|c|c|c|}
\hline \multirow{3}{*}{\multicolumn{2}{|c|}{$\begin{array}{l}\text { Total Petroleum Systems } \\
\text { and Assessment Units (AU) }\end{array}$}} & \multirow{3}{*}{ Type } & \multicolumn{12}{|c|}{ RESOURCES } \\
\hline & & & \multicolumn{4}{|c|}{ Oil (MMBO) } & \multicolumn{4}{|c|}{ Gas (BCFG) } & \multicolumn{4}{|c|}{ NGL (MMBNGL) } \\
\hline & & & F95 & F50 & F5 & Mean & F95 & F50 & F5 & Mean & F95 & F50 & F5 & Mean \\
\hline \multirow{8}{*}{ 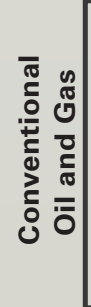 } & \multicolumn{14}{|c|}{ Upper Cretaceous-Tertiary Coalbed Gas, Total Petroleum System 504101} \\
\hline & \multirow{2}{*}{$\begin{array}{l}\text { Upper Cretaceous-Tertiary Sandstones } \\
\text { AU } 50410101\end{array}$} & Oil & 0.00 & 0.00 & 0.00 & 0.00 & 0.00 & 0.00 & 0.00 & 0.00 & 0.00 & 0.00 & 0.00 & 0.00 \\
\hline & & Gas & 0.00 & 0.00 & 0.00 & 0.00 & 17.52 & 54.00 & 113.12 & 58.53 & 0.54 & 3.00 & 0.00 & 0.00 \\
\hline & \multicolumn{14}{|c|}{ Jurassic-Cretaceous Composite, Total Petroleum System 504102} \\
\hline & \multirow{2}{*}{$\begin{array}{l}\text { Fractured Reservoirs } \\
\text { AU } 50410201\end{array}$} & Oil & 0.00 & 0.00 & 0.00 & 0.00 & 0.00 & 0.00 & 0.00 & 0.00 & 0.00 & 0.00 & 0.00 & 0.00 \\
\hline & & Gas & 0.00 & 0.00 & 0.00 & 0.00 & 14.64 & 78.04 & 199.31 & 88.76 & 6.86 & 23.29 & 8.35 & 3.54 \\
\hline & \multirow{2}{*}{$\begin{array}{l}\text { Jurassic-Lower Cretaceous Reservoirs } \\
\text { AU } 50410202\end{array}$} & Oil & 0.00 & 0.00 & 0.00 & 0.00 & 0.00 & 0.00 & 0.00 & 0.00 & 0.00 & 0.00 & 0.00 & 0.00 \\
\hline & & Gas & 0.00 & 0.00 & 0.00 & 0.00 & 184.48 & 605.39 & $1,073.12$ & 615.09 & 0.00 & 0.00 & 46.45 & 24.58 \\
\hline \multirow{8}{*}{ 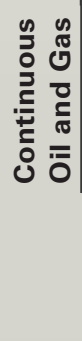 } & \multicolumn{14}{|c|}{ Upper Cretaceous-Tertiary Coalbed Gas, Total Petroleum System 504101} \\
\hline & \multirow{2}{*}{$\begin{array}{l}\text { Raton Coalbed Gas, } \\
\text { AU } 50410181\end{array}$} & Oil & 0.00 & 0.00 & 0.00 & 0.00 & 0.00 & 0.00 & 0.00 & 0.00 & 0.00 & 0.00 & 0.00 & 0.00 \\
\hline & & CBG & 0.00 & 0.00 & 0.00 & 0.00 & 316.65 & 572.83 & $1,036.25$ & 611.26 & 0.00 & 0.00 & 0.00 & 0.00 \\
\hline & \multirow{2}{*}{$\begin{array}{l}\text { Vermejo Coalbed Gas, } \\
\text { AU } 50410182\end{array}$} & Oil & 0.00 & 0.00 & 0.00 & 0.00 & 0.00 & 0.00 & 0.00 & 0.00 & 0.00 & 0.00 & 0.00 & 0.00 \\
\hline & & CBG & 0.00 & 0.00 & 0.00 & 0.00 & 584.10 & 939.31 & $1,510.54$ & 979.32 & 0.00 & 0.00 & 0.00 & 0.00 \\
\hline & \multicolumn{2}{|l|}{ TOTAL CONVENTIONAL RESOURCES } & 0.00 & 0.00 & 0.00 & 0.00 & 216.64 & 737.43 & $1,385.55$ & 762.39 & 7.40 & 26.29 & 54.81 & 28.12 \\
\hline & \multicolumn{2}{|l|}{ TOTAL CONTINUOUS RESOURCES } & 0.00 & 0.00 & 0.00 & 0.00 & 900.75 & $1,512.14$ & $2,546.79$ & $1,590.58$ & 0.00 & 0.00 & 0.00 & 0.00 \\
\hline & \multicolumn{2}{|l|}{ TOTAL RESOURCES } & 0.00 & 0.00 & 0.00 & 0.00 & $1,117.39$ & $2,249.57$ & $3,932.34$ & $2,352.97$ & 7.40 & 26.29 & 54.81 & 28.12 \\
\hline
\end{tabular}

